\title{
Replacement or Substitution in the Meeting of Religions
}

\author{
By CARL GUSTAV DIEHL
}

The following pages aim at making a contribution in a limited way to an investigation of the meeting of Religions.

\section{$I$}

Such a meeting may result in a perpetual existence side by side with no mutual contact or influence perceptible. Example are easily found. Christians, Muslims and Hindus have lived side by side in India for centuries with little or no contact. Individually they may meet and even be mutually present at religious functions but officially and through 'office-bearers' there was no contact except as attempts at replacement. Another example may be taken from Spain where Christianity and Islam lived for centuries together. Whereas the cultural history of Spain is exhibiting a rich array of products of art, literature and thinking as a result of mutual influence there is hardly any manifestation of religious exchange as far as the organized forms of Christianity and Islam are concerned. ${ }^{1}$

Geographical boundaries are not decisive in spite of the popular way of dividing the earth in Christian and non-Christian countries, Buddhist countries and others. Not even the political border lines drawn on principle between "daral Islam, that is extending the mundane area of Islamic control", 2 and the rest of the world is absolute. People of different faiths live side by side without meeting one another as far as their religious experience is concerned. The reason for this isolation in regard to one function of life while a mingling together in other spheres of life, e.g. professional work and cultural activities, is quite frequent, is to be found in the compact

1 Zaki Ali, "Der Einfluss der islamischen Kultur auf das Abendland". Islam und Abendland, pp. 107 ff. R. Konetzke, "Spanien". R.G.G., 3. Aufl., VI, p. 225.

2 W. S. Smith, Islam in Modern History, p. 37. New York 1963 ('57). 
structure of religious organizations and their firm hold and control of the individuals. Typical examples are found in the attitude of Christians to men of other faiths, in the isolation of the Muslims from the 'infidels', but also in the way Christian denominations keep their members separated from others. The new religions in Japan maintain a similar distinction with some exceptions.

Where the religious unity is of an organic character encompassing all aspects of life as in tribal religions, the contact with other religions has often been exclusive also in a territorial sense. In as much as the life of the tribe is a complete whole, there is no room for strangers or otherliness. This phenomenon is recognizable in the concept of Charam in the Old Testament ${ }^{1}$ and has parallels in Africa today causing inter alia disruptions in the political unification of modern states. Again the history of Christianity furnishes variants of the same phenomenon with the application of the principle "cujus regio ejus religio". Dissenters were not tolerated.

Examples of meeting of religions in the sense of official negotiations are rare. In the Koran 3:50-62, there is an allusion to a Christian delegation which came to Medina in the year 632 from Najran, a small town on the border to Yemen. It was headed by the Bishop and it came to find out what the new ruler of Arabia thought of them. They were given quarters in the mosque and had a debate with Muhammed about the divinity of Christ. No agreement was reached and the delegation returned to Najran with a letter of assurance of liberty to continue in their religious belief "as long as they lived peacefully and were honest in their dealings". ${ }^{2}$

The narrative reminds us not a little of the Church union negotiations in our time, but it differs from the number of consultations and proposals for better understanding and fellowship between religions which are also witnessed now-a-days. The Najran delegation was an official one, whereas today's efforts of approach are mostly private initiatives. Officially the religions continue to live in different compartments.

A peaceful co-existence of religions is of course not the only form of

1 Deuteronomy 7:2.

2 Translation of the Holy Quran by Muhammed Ali, p. 62. Lahore 1928 . R. Casper, "L'Eglise et l'Islam à la lumière du Concile". Parole et Mission, 34, p. 445 . July I 966 . 
meeting of religions. An enforced replacement of one religion by another was not seldom the consequence of military conquests. Examples of forced baptism or circumcision are less conspicuous than a consequence perforce of superiority of arms for the religious attitude of the vanquished people. Examples of a choice between conversion or death are not wholly absent from the history of Islam's Holy War, but a conquest through conviction is much more common as T. Arnold has very clearly shown in his book, The Preaching of Islam.

In India a development in the other direction has sometimes taken place. Superiority in arms did not always mean superiority in Culture. King Kaniska of the Kusānas represented an invading power of a different cultur but was converted to Buddhism, and although certain cultural influences are traceable to his original homeland, the religious life of India remained as it was, and the King "protected Jainism and Brāhmanism impartially". ${ }^{1}$

We need not go into the history of religious persecution. It should only be noted that it is not only just a form of conquest by violence, there is also a ruthless condemnation of the other religion in words and by all the means of the propaganda. Persecution as well as propaganda may at first appear to be merely destructive but the motive behind is mostly a faith of one kind or other that does not tolerate other thinking or behaviour. It is a kind of meeting of religions. The atheistic propaganda in Soviet Russia and elsewhere takes its strength from a conviction just as did the Spanish Conquistadors in their fight against the people of Mexico.

With due allowance for difference in means and methods the conquering spirit is behind all mission work whether done by Christians, Muslims, Buddhist, Hindu or others. The concept or conviction behind it is that a replacement must take place. The idea of exclusiveness is not tied up with political unity or dominance, although in actual implementation such motives may not be altogether absent. The exclusiveness is sometimes founded on the concept of Truth which in principle has replaced religious practices. The latter may also stand for exclusiveness and isolation, as is evidenced in Judaism and the dharma of the Brahmins, but where religion is conceived as Truth it tends eo ipso to be exclusive, and any meeting with other reli-

\footnotetext{
${ }^{1}$ Jeannine Auboyer, Daily Life in Ancient India (English translation), p. I4. London 1965.
} 
gions becomes a question of replacement. The obvious examples are to be had from the history of Christianity and Islam.

In both cases, however, Truth has been bedded in a pattern of religious life which perforce has then attained the same exclusiveness with a tendency for a demand of total replacement. A modification to a degree is noticeable though. There is a conscious effort to view religious customs and practices as dependent on local sentiment and mode of emotional as well as intellectual expression and therefore adjustable and subject to modification. There is also an unconscious adjustment to existing practices. It is here we meet with substitution. A few examples may suffice as an indication of how substitution takes place. Tukka Nivarti, ${ }^{1}$ cessation of mourning, is a ceremony observed generally by Hindus in South India. The sixteenth day after the death is commonly held to be the correct day for it. This "function" has been taken over by Christians. The ritual performance may be entirely different from the Hindu rites, but the urge to perform a ceremony of this kind has asserted itself and forced the Church to adopt a substitution. To continue with more instances of a functional perseverence in the treatment of the dead mention may be made of the custom of "turning the corpses" once a year. This is prevalent in Madagascar and observed by Christians as well as by others. In Tanzania, the custom of burying the dead outside the family hut is maintained also by Christians. As a consequence, there are hardly any cemeteries in that country. This is at any rate the situation in the North West district.

These and similar instances are evidences of an interfiltration of acts of religious behaviour that may take place as a result of a meeting or close coexistence of religions.

Such a meeting is in the first place an event with various consequences. Sometimes, however, the word is used for the result of a thinking process. In the hands of scholars, the material provided by the historical manifestation of different religions furnishes ground ${ }^{2}$ for an appraisal where they meet, i.e., where there are noticeable similarities and congruence of concepts.

1 Tamil spelling.

2 Noteworthy are the concepts of man as 'homo-religious' and the idea of "Christian presence" in all religions. See the series edited by Max Warren (SCM Press, London). 
This may be expected to serve as starting point for better understanding or even for an amalgamation, but since it is a theoretical effort, it seldom is of any practical importance, except within one and the same religion. It does play an important part in negotiations for Church Union among Christians.

An attempt at reaching a deeper level has been made by Raymond Panikkar in his book: The unknown Christ of Hindusim. From the intellectual scrutiny, he bores down to an existential level: "The meeting of religions is not merely an intellectual endeavour, not a simple practical problem; it is in itself a religious experience and a religious task." ... "Religions meet in religion."' This may mean that genuine religious experience would be the same and realized as such everywhere, but as a rule, not discovered, because of hiding conceptions and forms. It is, however, not the author's meaning simply to testify to a common ground for all mystics. There is also a reference to God's own activity which causes religions to meet in an eventful development, an interpretation of history, one might say.

Raymond Panikkar may contribute to a clearer understanding of the situation, but it is important to bear in mind that as far as an actual meeting is concerned, it has so far taken place in his own mind only. Something more will be said about the meeting of religions in the experience and thinking of individuals.

\section{II}

The meeting of religions is however not confined to a contact of organized entities. The situation was different when Christianity entered the scene of history. A. D. Nock in his book Conversion, ${ }^{2}$ describes it as follows: "In Greece, philosophy played the part of representing a religious attitude while elsewhere as in India, Babylonia and Egypt an organized priestly class comparable to an established Church stood as party at the meeting of religions." A situation such as in Greece at the time of the beginning of Christianity offers more chances for a meeting of religions whereby various elements mix than when clearly defined systems of cult come in touch with one another. In the first mentioned event the individual can choose and shape

1 Op. cit., p. Io. London 1964.

2 Op. cit., p. I64. Oxford r933. 
religious forms, whereas his behaviour and function in the latter case is largely determined by an authoritative class of religious leaders.

In a situation where no closed entities keep the adherents of different religions in isolation from one another conditions might prevail which are described by J. Gonda in general terms as far as ancient India is concerned thus: "Through assimilation and integration, a complicated inter-action of growing together and differentiation conditioned by the most variegated geographical, ethnographic and historical circumstances and by the appearance of numberless religious leaders." 1 The subject has merited a monography of 484 pages by the same author: Change and Continuity in Indian Religion. ${ }^{2}$ Obviously, no closer definition of what a meeting of religions mean can be had from these in themselves correct but general observations. The reason is chiefly found in the absence of clear conceptions of the units or subjects involved.

The old Church was facing a situation where the conditions for a meeting of religions were such as to make the general observations of Mr. Gonda applicable. Apart from the Jewish community strict religious authority was not rampart. The Hellenistic time has been qualified as one of individualism. ${ }^{3}$ This is evidently the background when Adolf von Harnack refers to the spread of Christianity with these words: "One was won through the Old Testament, another one through witnessing the casting out of demons, a third one through the pure life of the Christians, again another one through monotheism or most important of all-through the possibility of having total reconciliation and eternal life, or through the depth and social implication of the Christian thought. Often one believer would have stirred up another. The example - not only that of the martyrs - the personal presentation of the Christian life invited followers. Very few, to be sure, had a complete knowledge of the Christian doctrine." 4

Another author on the same subject, A. D. Nock, gives a very similar narration, ${ }^{5}$ "A pagan came in touch with the movement in many ways

\footnotetext{
1 Die Religionen Indiens, I, p. 214.

2 Hague 1965.

3 "persönlicher", R.G.G III, III, p. 2 I2.

- Mission und Ausbreitung des Christentums, I, p. 102.

5 Conversion, p. 212.
} 
quite incidentally. He happened to be a friend of a Christian. He might have seen or heard of exorcism. He had been present when a martyr wholly unintelligibly and irrationally suffered because of an idea and was tortured to deny or to confess. He had left the scene unable to understand the meaning of it. Or, he might have heard of the Christians as a dangerous organization tending to undermine society and leading an immoral life. That which is condemned by society sometimes exercises a fascinating attraction, and obstructing activities have an inherent appeal in themselves. Moreover, the lower strata of the population in the old classical age suffered from a distinct inferiority complex and from a pathetic desire of asserting themselves. In joining a society like the Church, they obtained some importance." The last sentence could be said about conditions prevailing in India today, except that the desire for self assertion is neither pathetic nor strong. There is a more mature movement for social uplift and political status, but in many individual cases, it is still-born or dying through inertia. "What I never expected from my African experience, was the indifference, the stridently silent lassitude of body and mind."1

There were also prearranged meetings when Christian messengers, preachers or theologians turned to non-Christians presenting Christianity for acceptance as the truth. According to Nock, this encounter in most cases took the shape of a kerygmatic announcement and not in methodical proselytization. ${ }^{2}$ In all cases, the relative freedom of the individual to choose is noticeable. The religious market was so to speak open and the result of the free intercourse was not altogether to the advantage of the Church. A. von Harnack sums it up in the words: "die volle Ausgestaltung des Christentums als synkretistische Religion". ${ }^{3}$

With individuals religions may meet in such a way that thoughts and concepts bring about afforts to integrate elements from different religions into a harmonious unity to the exclusion of other elements which do not fit. Something on the line Gonda indicates in general terms as taking place in the formation of Hinduism could have taken place in the early history of Christianity, because similar conditions prevailed.

${ }^{1}$ R. Segal, The crisis of India, p. I25. London 1965.

a Op. cit., p. I 88.

3 Op. cit., p. 300. 
There was no fast religious organization in either case. In a sense similar conditions prevail in India today with one important exception. The caste curbs the individual's freedom to follow different ritual patterns although on the other hand the freedom to choose and hold religious concepts and ideas is almost unlimited. Hinduism has no creed, it has been said. The statement is of course open to discussion. It will be taken up to some extent below. ${ }^{1}$

\section{III}

When we enter into the field where religions meet in the experience of individuals which was evidently the case in early Christiendom and for the most part characterizes all organized encounters of one religion with another they will in the first place be noted as alternatives. A certain qualifying terminology is, however, found in modern missionary parlour. Encounter is a term much used now-a-days. There is a certain amount of mutual experience inherent in the word. The Christian sees the Gospel as clearly different in a religious context instead of simply as an excluding entity with no relevance to existing religions. There is room for an exchange of thoughts, a dialogue, which however, from the Christian point of view, is expected to result in "Conversion". ${ }^{2}$ It is against this background a mission magazine is called "Encounter". 3

A meeting does take place in the sense that religious elements are confronted in the mind of a person but the result is, from the point of view of religions, status quo. The person who at the encounter does not come over will remain in his old religious tradition, and he who does come over enters into a new religious context which does not change through the encounter. While the religious traditions thus remain unaltered, the encounter may result in changes of the attitudes and reactions of the individuals over against their respective traditions. They may after the encounter, whether a "Conversion" has taken place or not, develop a new selectivenes in their religious behaviour and in their attachement to practices and ideas. In their

1 See below the evidences from Sunder Rao, Panikkar and Fakirbhai.

2 The meaning of the word may be left undefined here. It has various implications.

3 Or, "World Encounter" by the Board of World Missions of the Lutheran Church in America. 
looking for bearings in life thoughts and elements from different religions or differently emphasised in different religions may mix and form new concepts or even a new outlook, which the individual believes is in congruence with his "established" religion. In this way an endless variety in shades of syncretism may develop which is open only to studies of individual cases.

The meeting of religion in the sense of a real contact with mutual influence takes place far more often in the lives of individuals than it does in the life of religious communities. It is therefore difficult to map out, so much more so as very few are able to give a correct account of their religious experiences and concepts. ${ }^{1}$ Increasing individualistic trends breaking up the social patterns add to the complexity of the situation. Syncretism becomes more and more common and heretics more difficult to find out.

If it is a question of ritual or religious practice taken over by an individual from another religion than his own, as not seldom happens, the effect of the meeting is sometimes clearly perceptible. It has happened that a Hindu convert to Christianity continues to take his bath as a ritual ablution and even prefers as water for his bathing the so called "Tirtha", or sacred water. This is a mingling of elements from different religions. What are we to think of a Hindu death advertisement which ends: "May his soul rest in peace" or a Hindu writing in the guest book of his Christian host that he is grateful for this experience of "brotherhood of men and fatherhood of God"?

When an element reappears often and with many individuals the functional background may be considered. There may be specific reasons why a Christian touches the picture of Christ after having said a prayer but a need for tangible presence of the Divine might be revealed when many Christians repeatedly do so.

A practice or a way of reacting adopted by individuals may gradually obtain official recognition and sanction. While discussing a revision of the liturgical orders of the Church at a Pastors' Conference in South India, a speaker indicated that the proposed new handbook contained rituals for 52 different acts and occasions. Even so the demand for many more was voiced. That means, e.g., that Christians feel the need of rites for girls reaching maturity, the entering into new houses, celebrating anniversary of

\footnotetext{
${ }^{1}$ Cp. H. Von Glasenapp, Glaube und Ritus der Hochreligionen, p. I59. Frankfurt r960.

Io $-68_{438}$ r Hartman
} 
deaths, etc., practices which are in vogue among Hindus. Behind them may well lie a need for security on important occasions, whether practised by Hindus or Christians and in spite of great differences in ritual and texts.

History provides evidence of substitution in plenty. Places of pilgrimage serve to satisfy an urge to seek extra-ordinary help and the desire for the satisfaction of special effort and purposeful journeying. The sanctity and bliss of the place is caused by here this, there that saint. Nagore, a town on the east cost of the state of Madras is the venue of pilgrims of at least three religions.

The functional manifestations are however not new or recent in the respective traditions. Their history is not to be indicated in this connection. They serve as examples of religious functions finding expression in different religious contexts. Instead of saying "here this, there that", one could say: "now this, now that" because history also knows substitutions in time on the same place of saints of different religions. The Black Madonna of Guadeloupe in Mexico is a prominent example, but here belongs also the frequent substitution of temples of a new religion for those of another on the same spot. The sanctitiy of the place remains under a new garb.

In peoples' minds thoughts and concepts are developing and mingling and the result of it may be an attempt at integration, merging, harmonizing or exclusion, something like what J. Gonda found to be taking place at the birth of Hinduism. If and when the bearers are capable of spreading their ideas, they appear on the scene of world culture or in a more local setting with programmes for new religious outlooks. A. Toynbee and S. Radhakrishnan are outstanding examples as professing a religion of humanity built on supposed common religious needs and experiences.

There is on the side of Christian thinkers a similar attempt at revealing a hidden unity. Raymond Panikkar in his book mentioned above is digging for gold in non-Christian religious experience as the title of his book indicates. The unknown Christ of Hinduism is to be unveiled through a sort of Socratic "mayeutic" whereby Hindus realise the presence of Christ all the time in their own religion. ${ }^{1}$ The meeting of religions consists in a bringing forth of the one by the other. This concept of a meeting is not new. Already

1 Op. cit., p. 4.5 . 
in 1924, A. S. Appasamy in his book: 50 Years of Pilgrimage of a Convert has a chapter called "Anticipation in Hinduism of Christianity". ${ }^{1}$ In this case a conversion was found motivated after it had taken place through deeper insight in Hindu mysticism.2 Otto Wolff presents examples of Christ present with outstanding religious personalities within Hinduism. ${ }^{3}$ The meeting did not in their cases result in a change of outward religious loyalty, although it may have meant identification or an integration of their meeting with Christ in the building up of their personal religion.

Instead of giving literary expressions to the ideas born out of a meeting of religions in their own heart and mind some create new religions. The experience of the prophets of new religions may be of a different psychological structure than that of writers but basically it is a meeting of religions all the same. An element of spontaneity styled as "calling" or "revolution" may have to be counted with. The phenomenon which history of religions generally restricts to a few outstanding personalities like Mani, Muhammed, Kabir, etc. has appeared in manifold numbers of late. Suffice it to mention the "Sects" of South Africa and the "New Religions" in Japan.

In order to remain in the Indian sphere, Kabir may be called into memory as a personality where religions met with the result not only of 'Sikhism' as a religion of its own through Guru Nanak, but also of a lasting tradition of Gurus with their clearly marked individuality of religion the so called "Panths". 4 These new forms of religion have survived not in the least through a firm organization with its own scripture and cult.

Many of these new formations are however short-lived. This is evident from another Indian example. The emperor Akbar himself tried to amalgamate Islam, Hinduism and Parsism in what he called 'Din-i-Ilahi'. Akbar had exstatic visions behind his effort and could rightly claim to be something of a prophet and his religious enterprise to be more than the mere result of academic discussions which he introduced at his court. Nevertheless the thing failed. Not even imperial power combined with a presumably genuine religious experience could make it last. It remained a non-definable experience of an individual.

1 P. 89. 2 P. 94.

3 Christus unter den Hindus. Güterloh 1965 .

4 F. E. Keay, Kabir and his Followers, pp. $93 \mathrm{ff}$. 
By non-definable is meant not true to type. In most cases individuals who 'in their minds build up a vague system according to predilections and prejudices, which are impossible to account for' remain in their traditional religioius setting. A Hindu may embrace any kind of philosophy and even be an agnostic, but he remains a Hindu as long as he follows the conventional rituals of his community. This has another side in the meeting of religions caused by missionary activity. A convert may take over a new set of concepts bundled up like a parcel but remains fundamentally in his old traditions.

A prominent African scholar and Church leader warned against a Christian education which does not pay heed to the elementary functions of life for the exercising of which people depend on traditions inherent in tribal life. At the time of crisis the theoretical Christian training will be forsaken for emotionally deep-rooted ceremonies.

One of Africa's national leaders, a Christian with a theological degree, had ordered that no religion ceremonies should be held at the time of his death and left $£ 20,000$ to his private sorcerer. ${ }^{1}$

From South India an example may be had which is commonplace but significant. The Catechist of a small congregation was worried, he said to me in June 1966 , because he had discovered that members of his congregation performed Puja along with the Hindus and made pilgrimage to Palni and had their hair shaved as a sacrifice to Tandayudhan (Subramaniam). The meeting of religion has led to replacement in some departments of life. They observed Christian customs of attending service on Sundays; they had their children baptized and their young couples presented in the Church for the wedding ceremony of the Church² but other departments of life, such as some social bonds which are manifested in festivals and communal activities and also the resort taken at times of sickness and worry for bodily health had not been replaced, nor was any substitution found in the Christian living.

The distinction should be maintained between remaining elements from one religion with people who have entered into another religious context, and substitution of contexts for the same function. If Christians go on

\footnotetext{
1 From a conversation with Prof. Christian Baëta.

2 In 1967, however, a complaint was made against a Christian young man who married a Hindu girl with a ceremony at the Kurinji Antavar (Murukan) temple.
} 
pilgrimage to Nagore and sacrifice to Our Lady of Velankanni, it is a substitution. When people give up the idea of going on pilgrimage and have prayers said in a Church for their recovery from illness, it is a replacement of the pilgrimage as a religious function by something else.

\section{IV}

In looking for evidences of substitution, the following instances have presented themselves from casual observation and not from systematic investigation. People of all religions will give expression to their needs and desires under forms which come under the general term of prayer. It is a kind of substitution when a Hindu who used to stand in adoration in front of Kali, while his lips moved in silent whispering after conversion takes a similar position in front of Mary. Substitution is often recognizable with regard to details. The experience of touching a concrete manifestation of the divine is apparently longed for in many places. In the Minaksi temple at Madurai, one after another of the many visitors in the evenings can be seen touching the big Mukuruni Ganesa's feet or stomach and smear ashes on his forehead. Many walk around the redpainted figure of Hanuman, touch him and apply some of the colour to his own head.

On June 2oth 1966, a Wednesday, some instances of private prayer were observed in a Lutheran Church in Madras. A young woman came to the altar, stood for a while moving her lips in prayer. She then bowed down and touched the floor with her forehead, and then she walked over to the wall at the side of the altar and touched an ordinary picture of Christ carrying his cross, three times. Every time she touched the picture she passed her hand over her forehead. The fact that this took place in a protestant Church where the need for a spiritual relationship to God is emphasized is worth noticing. The touching is not to be taken as magic but as an element of religious behaviour which can appear in different contexts.

Another example from the same place and time may be taken as a simple evidence of the significance of offerings. An old, blind woman was conducted up to the altar railing by a young relative. She sat down as old people do with her legs stretched out in front while she was praying, and then she was led up to the railing to lay a coin in the collection box which was fixed 
to the railing. The place of the collection box is in itself an indication of the need felt for bringing offerings to the sacred place. Similar arrangements are found everywhere in South India. Three places may be mentioned to bring the phenomenon in the concrete. Along the road to Tranquebar at the outskirts of Mayuram, there is an image of Muniandi. $\mathrm{He}$ is also standing at the foot of the rock at Tirumayam, south of Pudukkottai. A coconut is smashed by bus-passengers in both places and coins are dropped in the collection box at his side. Outside Nagercoil at the Three-Pandal-Yesaki temple, the buses will stop while a servant of the temple brings a tray with sacred ashes. Some passengers take some of it and apply it to their foreheads and drop some coins on the tray. The sincere prayer of the blind woman may be a replacement as far as its contexts are concerned but the "obligatory" offering is more of a substitution. As Christian, she would know herself welcome to pour out her heart to God, but the practice prevailing laid down in the proverb: "One must not come emptyhanded to the temple" is more of a substitution.

As more and more examples offer themselves for annotation, the term "manifestations" presents itself in the sense of Van der Leeuw's book. ${ }^{1}$ The phenomenology of religion would recognize a number of elements which are found in different religious contexts as a sort of mental constants reappearing again and again in different garbs. The following incident could be quoted in support of it. The idea of a saint is met with in a narrative from I4th April 1966. C. P. Michael writes about an improvised sunrise service held on the beach just below St. Thomas Cathedral in Madras not far from the temple of Valluvar, the famous author of the Kural, the gem of Tamil literature. The environments makes the writer express himself in this way: "Most of us were sitting on the shore sanctified by the footsteps of the Apostle of Christ and the Tamil Saint." 2 The writer himself a Christian, counts with saints as a common phenomenon to Christianity and Hinduism. The point we would stress here is, however, the urge to create an image of exclusive, although attractive, figure or way of living which stimulates feelings of awe and adoration. In other words we seek the urge and need behind the manifestations and not the phenomena themselves.

${ }^{1}$ Religion in Essence and Manifestation. London 1938.

2 "The Guardian", Madras, Vol. XLIV, No. r9, p. r52. May 1966. 
Exchanges of elements from one religious context to another are sometimes made quite intentionally on an assumption that they are inter-changeable, Jack Winslow in his book: The Christian Approach to the Hindu, writes as follows:" At our ashram (Christa Seva Sangh, Poona), we used to gather daily for worship at dawn and at sunset, the times of the day that are called Sandhyā, points of contact between day and night, which have of old in India been set apart for meditation and prayer. On these occasions, we used to sing the beautiful Maratha songs of N. V. Tilak along with our Bible reading and prayers to the accompaniment of drums and cymbals. Afterwards the leader would exhort those that were present to lift their hearts to Christ, the true light, and all joined in reading aloud the Gayatri Mantra in Sanskrit-that old invocation by the repetition of which again and again the Hindu collects himself in concentration in order to come before the Eternal Being.-There followed a period of silence as at a meeting of the Friends and at the end all joined in the well-known Sanskrit prayer: "Lead me from the unreal to the real. From darkness lead me to light and from death to immortality, accompanied by the quiet accord: Santi, Santi, Santi."

Regular hours of devotion is a common feature. The offices of the Church would fit in with the Sandhya practice of the Hindu. Mr. Chenchiah, a Christian advocate of Madras, once refers to his observing of Brahma Muhurta, the early hours before dawn, as a link between himself and a Hindu friend. Such a substitution of Sandhyā for morning and evening prayers would come quite naturally to a convert from Hinduism to Christianity as well as, in this case, to Christians eager to adopt Indian customs in their religious behaviour.

The loan of old Sanskrit texts would perhaps be more of an artistic refinery than a genuine religious need, since ample substitution could be found in the Christian oratories.

It is not out of place to point to substitution as not merely of gesture and other kinds of external manifestations but also of inward sentiments. An outsider will have to be cautious in taking religious acts and ceremonies at their face value. Much of underestimation and miss-judgment has its root in a failure to penetrate to the religious sentiment behind the façade. ${ }^{1}$ People

1 The opening chapter in MacNicol's The Living Religion of the Indian People, rev. ed., 1964 , is in this respect really out-dated. 
are not entirely wrong when they pretend to find such elements in their own religious traditions as are applicable and alive to the need of modern man in other religions. A typical example is the claim of Hinduism to be comprehensive with regard to the religious functions of man. "Each and every system has a corner in the Hindu ideal of spirituality." Religious elements could have been functioning earlier and later become forgotten. It is on the other hand equally true that historical mistakes are often made when ideas of modern man are read into old texts and orders. There is, one might rightly say, an almost endless field for substitutionary thinking in the matter of text interpretation. The substitutions of modern religious thoughts are clearly apparent e.g. in the commentaries of the Bhagavad Gita ${ }^{2}$ and in the regular religious discourses held daily or weekly in India. It would be worthwhile quoting from the engagements column in "The Hindu", Sunday I8.6.67, only it may be too long with its 19 items of religious lectures and discourses. Let us look at just three of them.

"Ishwara Gnana Yoga Patasala: Mr. B. K. Chanda speaks on "The supreme act of God", 6.30 p.m."

"Discourses: Brahmasuthram by V. Kalyanasundara Sastri, Upanishad Ashram, Nungambakkam, 7.00 a.m.

Ramayanam by E. R. Sundararaghavachari, Ranganatha Temple, George Town, 7.30 p.m."

As examples of their contents, the following quotations are given from reports in "The Hindu". On May the I7th 1967 , an article on "Two Principal purposes of God's Incarnation" begins: "Of the twin principal purposes of divine incarnations--to protect the virtuous and punish the wickedemphasis according to the great apostles, is placed more on the former aspect" ... "God came to the rescue of the child-devotee Prahlada." "In his Bhagavatam discourses in George Town, Sri Karpangadu Venkatachariar said in no incarnation had God taken the lead over His opponent and killed him immediately with his own hands."-It is not merely the

1 Harendranath Maitra, Hinduism the World Ideal, p. Io3.

2 Swami Chidbhavananda (The Bhagavad Gita, p. 192, Tirupparaithurai 1965) paraphrases "Matparah" in II :6r.- "I shall delight in the glory of the Lord": while the translation is "intent on me". 
use of Christian terms like incarnation and apostle but this substitution of acceptable and inspiring religious ideas for the more literal contents of the text that makes this an evidence in casu.

A more subtle substitution can be found in another lecture on Ramayanam reported in "The Hindu", 29th April 1967. "If Sri Sita,-who had Paramatma Himself (Rama) as Her spouse was lured by the beauty of a deer, it could only be attributed to the adversity of time. Again, when Lakshmana goaded by Sri Sita went in search of his brother, he could have taken Her also with him, instead of leaving Her alone.-But these did not happen, because God had ordained so." The defects in the behaviour of the divine persons are explained $(a)$ by reference to astrology, i.e., of a different context altoghether, $(b)$ by reference to a monotheistic faith and its implications.

The vague concept of mysticism is found as a common ground by a Christian convert who writes "Mysticism is my Realization of the infinite in man, and the Realization of my existence in Him". ${ }^{1}$ A substitution of object in the experience of mysticism is demonstrable in some more recent publications. Works like Khristopanishad by Dhanjibhai Fakirbhai and Ananyatva by M. Sunder Rao, use traditional Sanskrit term to express their experiences of Christ like Ekam Eva Advaitam, ${ }^{2}$ One without another. Jesus is "sometimes sensed, felt and experienced as ultra-personality, the ultimate, infinite and eternal". ${ }^{3}$ The substitution of Jesus for Brahman makes one wonder if the "carrier", the terminology, is not sometimes too strong to allow a substitute. The words: Ekam Eva Advaitam trend to hold the concept as well as the art of experience in a firm grip of uniqueness. While the mystic approach to the utmost reality is tried in different contexts the emphasis on divine presence in this world is equally apparent. When a Christian preacher says: "Christ is the part of God turned towards the world", he is coming very close to the language of the Sakti idea in Hindu thought. Sakti is just that, the approach of the non-conceivable One, existing in itself alone, to the world.

The acts of substitution in realizing the divine presence are usually more tangible. A Church is substituted for a temple and a Christian iconographic

1 J. N. Swami, Christananda, p. 53. Madras 1934.

2 Khristopanishad, p. I. Bangalore 1966.

3 Op. cit., p. 9. 
representation fills up the place of an idol. This is quite natural and obvious but mostly thought of as replacement and not as substitution. There is, however, a need for the presence of God in all religions in whatever way it is thought to be realized. Such a need is e.g. behind some words quoted from a Christian preacher of a denomination which does purposely avoid all representations of the Divine presence in the form of pictures or altar arrangements. He said with warmth and conviction in his voice, "Christ is amongst us today in an absolutely realistic manner just as 2000 years ago". When the author himself asked a Hindu, on the road side why people worshipped idols and not God who has created us, his answer was as if taken from a text-book on 'High-gods'. "He is too far away. He is not near us." This man would meet his God in the shape of Ayanār or Muniyāndi whereas the Christian preacher is thinking of an unnoticeable presence of Christ. He may, however, also have in mind another kind of presence, namely the inner experience. This is much in line with the witnesses to Christ among Indian Christians of high intellectual standard. Professor Dhanjibhai Fakirbhai says in the preface to Khristopanishad:1 "These thoughts have arisen out of personal experience and revelation." A personal experience is also related in the beginning of the book with the comment: "Ever since that time Jesus has been to me God, and I have never had to go back on that revelation."2 This may be considered a genuine replacement. On the other hand, the emphasis on experience is also, as B. H. S. Boyd says in the foreword, due to professor Dhanjibhai's bhakti tradition in this early life. ${ }^{3}$ The psycho-somatic conditions required for an experience may be considered to be similar and the important thing to take note of is that the object of experience does not change. One is of course reminded of Ramakrishna's experiments in realising the presence of now Kali, now Allah and now Christ, but the rule is as in the case of Professor Dhanjibhai that once an experience of the presence has occurred, no other "apparition" is met with. Experience, Anubhava, is also the keyword in Mark Sunder Rao's book. The goal is a unity with God, Sayuja, but not identification. Non-otherliness, Ananyatva is the term used along with Tatva, Hita and

\footnotetext{
1 Op cit., p. XV.

2 Op. cit., p. 5 .

3 Op. cit., p. XIII.
} 
Purusarrtha as describing the nature, the way and the fulfilment. Significant is the term 'Poorna Yoga' which Sunder Rao uses for the text: "I am the real vine etc."1

Different evidence is to be had from a notice in "The Hindu" of $17^{\text {th }}$ May 1967. "A Buddhist nun turned herself to death in a pagoda in Saigon today ... Behind the body which was bent forward in a kneeling position lay a white cloth on which the nun had written in black: 'Virgin Mary and Goddess of Mercy help me to fulfil my prayer'. A statuette of Buddha (Kwan Yin?) and another of the Virgin Mary stood in front of the body." Here the two manifestations of divine mercy were evidently capable of substitution, the one for the other.

A representation of the Divine in effigy is objected to in Christian circles, particularly of an evangelical type, but the need for real contact is felt and finds expression in the form of intensive experience. The emotional stir is sometimes taken to be proof of the reality of the contact established but it is different from the mystic's union with the Divine. The distance between the human and the Divine is maintained even in the experience of its close presence. To overbridge or endure the alienation the concept of reconciliation or atonement is born.

Mark Sunder Rao from his earlier Hindu background attempts at an understanding of the atonement with God as answering to a general desire in man and would find it as an experience in both Hinduism and Christianity.

It is, however, through splitting up the word in its component parts that Sunder Rao finds that "a deep and abiding soteriological concern is the common feature of both Hindu and Christian faiths". ${ }^{2}$ The at-one-ment is aimed at, he says, in the terms of the Vedanta but realized in Christ, and for the new relationship he chooses not Advaita or any variation of the term, but Ananyatva - non-otherliness. To evaluate the merit of the term a separate study may be required. It seems to take care of the ethical as well as the mystic conditions for at-one-ment but less of its factual radicalism. The point, however, is that a general religious function, the need for reconciliation with God, admits of substitutionary concepts, although Sunder Rao finds the complete realization in Christ only. The question of replace-

${ }^{1}$ John I5: I ff.

2 Ananyatva, p. 39. Bangalore 1965 . 
ment is answered in the terms of completion rather than in terms of something entirely different. The experience is not considered to be new, only its fulfilment.

As a side issue of the reconciliation concept, the question of fate comes in. To reconcile one's self to fate is one thing, but a religious issue is met with in the more common attempts to reconcile fate to one's own desire and aspiration. Here we should have to deal with all the efforts on the side of man to placate the powers and gods. The question arises whether such efforts are made in different religious contexts, and if thus one method or ceremony is just substituted for another. When Christians go on pilgrimage to Palni, it is a matter of Hindu custom remaining in force. When, however, Christians take their cattle to a priest at Pongal in January to have them blessed by him, a substitution is made of one religious context for another for the same functional element.

Again we find a more subtle distinction in the following account of religious care of patients in hospitals.

The Superintendent of a mental hospital at Bangalore addressing people who had gathered to celebrate Buddha Jayanti, the birthday of Buddha, said that a Ganesa temple was established three years earlier inside the hospital campus. She continued: "Congregational prayers conducted every day had helped to create an atmosphere of emotional liveliness and religious fervour. The in-patients began to play on the various musical instruments, and bhajans (song-services) became the routine order of the day. The psychological revolution thus created, helped them to behave more rationally towards one another. ... Two patients who had been in the hospital for ten years showed the extent of their recovery by delivering speeches in Kannada and English, respectively on the significance of Buddha Jayanthi and their conception of what they felt to be their communion with the Infinite." 1

The resemblance to chapels and services in Christian hospitals is obvious. Noticeable is the intermingling of conceptual elements from different religions. It is not the custom to have congregational prayers at shrines erected to Ganesa. The whole concept is Christian. Again the Buddhists

1 "The Hindu", 23rd May r 967. 
would hardly speak of "communion with the Infinite". The important observation to make, however, is of the adaptation of a religious function, the congregational worship, to a different context than that where it is usually practised. The healing effect is a practical purpose of importance and hence appreciated and adopted.

A similar aim is recognizeable in the use of scripture as recommended by the Gideons. We find a printed guide for the use of the Bibles distributed to hotels. "Where to find help-when disorder threatens-when facing a crisis, when sick or in pain, etc." The Bible passages recommended are comforting and instructive, but noteworthy in this context is Proverbs I0: 12 which is suggested to him who thinks everything goes against him-in business particularly: ${ }^{1}$ While granting a total difference in context an example from popular Hinduism is yet instructive. H. Presley has, in "India Culture Quarterly", printed so called Chalisas or "devotional manuel of the mani-inthe street" addressed to different deities. One such Chalisa to Durga contains 39 short verses out of which Nos. 23 to 28 may be quoted:

23. He who meditates on the Mother will always be successful.

24. He who utters prayers to the Goddess will not meet with accidents not even in his dreams.

25. A man who is deeply in debt should repeate the name of the Goddess a hundred times.

26. He who utters such prayers wholeheartedly will be finally relieved of his debt.

27. He who reads songs of praise, or engages others to do so, will obtain endless happiness in this world.

28. Brother, if someone is suffering from disease, he will have his health restored by reading or uttering prayers to the Goddess.

It is quite natural to find people voicing a request for Scriptures in hotels, not only the Bible and "the Teaching of Buddha as in Japan", one reader writes, "but also Bhagavadgita and the Koran".

The utility of mantra reading is expressly stated in a number of Hindu

1 From new edition of 1966 , Stockholm. 
textbooks. ${ }^{1}$ Among Christians the use of prayer sometimes comes near to a similar practice as e.g. prayers for success in examinations which not seldom will be attended also by students who do not otherwise lead a life of prayer.

An indication of the frequency and limit of substitution can be had from P. D. Devanandam's book, Preparation for Dialogue. The late leader of the Christian Institute for the Study of Religion and Society writes: "Contemporary tendencies in the renaissance of the religions in our world seem to indicate that however much we as believers may part from one another in our different concepts of salvation, Moksha, we all attempt to reach the same goal in the way of living, Dharma, in the use of material goods for spiritual ends, Artha, and in the complete development of the human. personality, Kama. Are these then common fields for religious cooperation in which we ought to engage ourselves diligently, while we are anxious to preserve the Christian message, the Gospel about the Kingdom which is the Christian concept of Moksha?"2

The statement might to some extent be corroborated through a comparison of a hymn from the Hymnbook of the Church of Sweden with a passage in the Bhagavadgita.

A free rendering of the Swedish hymn runs as follows:

"Our God is a brave Hero who does not send peace but a sword. His belt is righteousness and with justice he judges his world.

When right and truth are threatened, he rises in just anger and blackest darkness turns to light when the Lord brandishes his arm."

The obvious parallel is Bhagavad Gita, IV: 7-8:

"Whenever there is decay of dharma and rise of adharma, then I embody Myself, O Bharata.

1 E.g. Atmabodha-upanishad ends with these words: "Whoever recites this for a Muhurta [p. 48, minutes] is not born again ..." Sp. Srisullam, p. 16. To the commonly read Srirudram the commentator adds after the first Mantra: "By reading this Mantra repeatedly all sins are removed, the Lord's full favour is established and Siva's departure prevented."

2 Op. cit., pp. $176-177$. 
For the protection of the good, for the destruction of the wicked and for the establishment of dharma I am born age after age."

If the different contexts can be kept in the back, the parallel is not farfetched indeed. The functional implications are very similar. The evil in this world is checked by super-natural interference coming spontaneously when the need arises.

The examples presented are culled at random but selected and arranged so as to cover different forms of religious life. The meeting of religions may mean a complete change of context in the sense that a person takes over a set of concepts and traditions entirely different from what he had in his old religious setting. This happens when a person passes from Hinduism into Christianity or Islam or vice versa. The open question, however, is to what extent the new concepts are but substitutes for other expressions which a religious function has taken and if the function remains essentially the same.

In some cases this is obviously so as e.g. when a Christian wears as an amulet a Cross with the name Jesus in the same way as a Hindu wears as copper sheet with a sextant and the words: Nama Sivaya-Praise to Siva.

A recognition of this fact may be said to be behind the recommendations and suggestions that the Church in India after a critical scrutiny and selection should adopt ceremonies and festivals prevalent among the Hindus. ${ }^{1}$

The initiatives have, however, hardly led to any official action and for a study of the substitutions we are mainly restricted to individual evidences like those listed above. Looking at the testimonies of individuals, we are faced with the problem to the extent that we may ask if replacement can at all be spoken of. The decisive point then will be touched with the question: What does the context really mean? Already the hint was made that the "carrier", in that case the Advaitic terminology was determining the issue to the extent that the monistic mysticism was almost indifferent to the characteristics of its object. The advaitic experience is claimed to be a meeting with reality in the fullest sense of the word, and if substitution can take place-exchanging Christ for Brahma-the question of replace-

1 Cf. C. G. Diehl, Church and Shrine, p. I77. J. Winslow, The Christian Approach to the Hindu, p. 57. D. Dasen, Pongal Day Speaks, Madras I966. 
ment is theoretically dispensed with, also for the simple reason that God is not open for research.

The ultimate question if religions are and can be substituted for one another cannot be answered by refering to individual cases since our means of knowing what really takes place in man is limited. As for the religious organizations, they claim to be replacements and not substitutes for one another. This claim may be found to be substantiated in their structure and thereby open to sudy. What amounts to a replacement in South India is the arrangement made by Protestant Churches in particular for listening to the word of God. Many small chapels are found in the villages, simple in form and without any sign or representation of the Divine, apart from a Cross. The interior is just a hall with an altar attached to one of the walls. Its purpose is to accommodate people and to provide queietness and an atmosphere of calm and expectation, not to provide any sort of show. In this respect it differs widely from the Hindu temples where figure and paintings and implements attract the attention of the visitors. The poorness of the Christian village church is not seldom contrasting rather markedly to the gaudy colours and life-size figures of village Hindu deities. Life comes to the chapel when the congregation is there and the Word of God is read and preached. There is nothing to distract the mind of the people from listening nor is there any concentration on the religious behaviour of man. He is spoken to, that is all, and then he may talk in prayer and singing.

This structure of Christianity as manifest in some section of the Church in India emphasizes the 'text' strongly and almost exclusively so as to disconnect it to a very large extent from the functions of religious life where substitution is generally found to take place. One could express it in Christian terms thus: God cannot be substituted. From the point of view of the study of religions the phrase may well be accepted since its terminology is general. It need hardly be added that by no means is a complete picture drawn of the manifestation of Christianity in India. Substitutionary elements can be found in plenty in Roman Catholic Churches and in Protestant Churches also. The simple need of looking in the direction of something is met by the altar, a Cross or a picture. It is almost a universal custom to take off one's shoes before entering the chapel to mark its sanctity, etc. But there is a noticeable reality behind the talk about the "dumb idols" in so far as they 
are to be seen and not heard. They are served by the devotees whereas the Christian service is taken as God serving man with his lifegiving Word. These concepts are more or less clearly manifested in the existing structure of the Church whereas temple worship is more of a religious function with emphasis on man's action. 